Article

\title{
Breeding Wheat for Resilience to Increasing Nighttime Temperatures
}

\author{
Kathleen Russell ${ }^{1}$ and David A. Van Sanford ${ }^{2, *}$ \\ 1 Agricultural Experiment Station, Colorado State University, Fort Collins, CO 80523, USA; \\ Katie.Russell@colostate.edu \\ 2 Department of Plant and Soil Sciences, University of Kentucky, Lexington, KY 40546, USA \\ * Correspondence: DVS@uky.edu; Tel.: +1-859-338-2409
}

Received: 14 February 2020; Accepted: 3 April 2020; Published: 8 April 2020

\begin{abstract}
Increases in global mean temperature since 1960 are largely attributed to the rise in minimum nighttime temperatures thereby decreasing diurnal temperature variation. Increased night temperatures are known to affect crop development. A multi-year study investigating the effects of increased night temperatures on soft red winter wheat (Triticum aestivum L.) varieties was conducted during the 2015-2016 growing seasons at the University of Kentucky Spindletop Research Farm in Lexington, KY. Thirty-six cultivars and breeding lines were chosen based on their genotypes at photoperiod and vernalization loci. This material was planted in a randomized complete block experiment with two replications and two environments, control and passively warmed. To create a passively warmed environment, thermal covers were mounted to frames in plots and connected to a datalogger programmed to cover plants from dusk to dawn based on coordinate location. Night temperature increases ranged from $0.27-0.75^{\circ} \mathrm{C}$ above ambient temperature. Grain yield, averaged across genotypes, was significantly reduced in the passively warmed environment by $224 \mathrm{~kg} \mathrm{ha}^{-1}$ $(p \leq 0.05)$ or $6.44 \%$; however, yield response to environment varied among genotypes with several genotypes displaying an increased yield in the warmed environment. Yield reductions may reflect reduced nitrogen utilization $(9.4 \% ; p \leq 0.001)$ under increased night temperatures.
\end{abstract}

Keywords: climate; heat stress; soft red winter wheat; photoperiod; nitrogen use

\section{Introduction}

Climate models generally predict an overall mean temperature increase when forecasting future variability in climate, however the minimum nighttime temperature may have a greater overall effect on plant growth [1,2]. According to the US Global Change Research Program, nighttime temperatures have been rising more rapidly than daytime temperatures and are expected to continue to rise in the future [3]. Accordingly, the increases in global mean temperature since 1960 are largely attributed to the rise in minimum nighttime temperatures, thereby decreasing diurnal temperature variation $[4,5]$. Increased night temperatures have been observed in the North American wheat belt among other areas of both Northern and Southern hemispheres [6]. Increasing night temperatures pose a unique threat to crop production and grain quality, impacting leaf area expansion and phenotypic expression of oil contents among other effects $[4,7]$.

Plants require favorable nighttime temperatures to maintain adequate respiration rates [2]. If respiration is increased, overall crop growth rate is slowed and decreases in biomass accumulation and grain yield are expected [8]. Increased nighttime temperatures are particularly critical for the reproductive phase of development due to the increased respiration rate and the reduction in the amount of carbon uptake from photosynthesis during the day being retained in the grain [9]. The increase in dark respiration rate is associated with a reduction in biomass and grain yields [10]. Prasad et al., 
2008 [11] observed decreased photosynthesis in wheat after 14 days of stress (nighttime temperatures above $14{ }^{\circ} \mathrm{C}$ ) causing grain yields to decrease linearly. Nighttime temperatures above $20^{\circ} \mathrm{C}$ caused a reduction in spikelet fertility, grains per spike, and grain size [2]. Hein et al. 2019 [12] induced nighttime warming $\left(+3.2{ }^{\circ} \mathrm{C}\right)$ during grain fill across 12 genotypes with 11 having a negative yield response. The average reduction in yield was $20.3 \%$ with a range from $6.1 \%$ to $41.4 \%$. In contrast, several simulated and field warming studies have seen an increase in grain yield despite a shortened vegetative growth period $[13,14]$.

Due to a number of physiological mechanisms, increased nighttime temperatures likely have a greater impact on cool-season $C_{3}$ species, like winter wheat, but the negative impacts can be seen on warm-season $\mathrm{C}_{4}$ crops, like corn (Zea mays) as well [15]. The increase in night temperatures results in more rapid growing degree accumulation leading to earlier maturation, shortening the grain filling period. This acceleration in phenological development results in reduced kernel weight [16,17].

Due to the difficulty in inducing increased nighttime temperatures, most studies focusing on a decreased diurnal temperature range are based on modeling data or are performed in controlled-chamber experiments. These studies rarely consider the genetic variation in response to nighttime warming that may exist. The objectives of this study were to (1) quantify genotypic variation in traits affected by passive canopy warming during night hours, and (2) assess the relationship between nitrogen use efficiency (NUE) and the ability to maintain grain yield with increased night temperatures based on genetic variation in traits related to $\mathrm{N}$ dynamics in the plant.

\section{Materials and Methods}

\subsection{Site Description and Experimental Design}

This study was conducted at University of Kentucky Spindletop Research Farm in Lexington, KY $(38.1304 \mathrm{~N},-84.4913 \mathrm{~W})$. The site is characterized by a Maury silt loam soil (fine, mixed, semiactive, mesic Typic Paleudalfs soil). We evaluated 36 soft red winter wheat genotypes selected based on photoperiod sensitivity alleles at the (A1/D1) loci determined using KASP genotyping chemistry (LGC, United Kingdom) analysis (Table 1).

The experiments were planted on 4 November 2014 and 20 October 2015. The warming infrastructure dictated the layout of the experimental design: the experimental unit was a headrow $1.5 \mathrm{~m}$ in length with $17.8 \mathrm{~cm}$ between rows. The 36 genotypes were replicated twice within each treatment; treatments were the control (ambient) and the warmed environment. The experiment was analyzed as a randomized complete block design grown in two environments, analogous to a standard genotype $x$ environment study that breeders use to test breeding lines. The warming infrastructure consisted of $1.8 \mathrm{~m} \times 6.1 \mathrm{~m}$ woven thermal covers (Hummert International, Earth City, MO) attached to aluminum frames. The thermal covers were mounted to the frames using $3.8 \mathrm{~cm}$ diameter PVC piping and controlled with small motors. The covers were rolled open during daylight hours and closed over the plots during nighttime hours using a timer programmed for the specific field GPS coordinates and time zone. Installation of frames occurred when soil was thawing and wheat plants were in "green up" or Feekes 3.0-4.0 and remain covered during nighttime until maturity.

Nitrogen was applied as liquid urea ammonium nitrate (28-0-0) formulation for the 2015 season using a backpack sprayer (R\&D Sprayers, Opelousas LA) and TeeJet flat fan nozzles (Teejet Glendale Heights, IL) and as pelleted urea (46-0-0) in 2016. A total of $112 \mathrm{~kg} \mathrm{~N} \mathrm{ha}^{-1}$ was applied in a $34 \mathrm{~kg} \mathrm{~N} \mathrm{ha}^{-1}$ and $78 \mathrm{~kg} \mathrm{~N} \mathrm{ha}^{-1}$ split on and 24 March and 13 April 2015 and as a single application of $112 \mathrm{~kg} \mathrm{~N} \mathrm{ha}^{-1}$ on 24 March 2016 because weather conditions were not favorable for a split application. Additional management was based on University of Kentucky Extension recommendations. 
Table 1. Panel of 36 soft red winter wheat genotypes with photoperiod (PPD) and reduced height (Rht) classification determined by marker analysis at two PPD and $R h t$ loci. These lines were tested under control and passively warmed environments, 2015-2016 growing seasons, Lexington, KY.

\begin{tabular}{|c|c|c|c|c|}
\hline \multirow{2}{*}{ Genotype } & \multicolumn{2}{|c|}{ Photoperiod Loci } & \multicolumn{2}{|c|}{ Reduced Height Loci } \\
\hline & $P P D-A 1$ & PPD-D1 & $R h t-B 1$ & Rht-D1 \\
\hline TRUMAN & Sensitive & Sensitive & Dwarfing & Standard \\
\hline GA04121-11E26 & Sensitive & Sensitive & . & \\
\hline PEMBROKE 2008 & Sensitive & Insensitive & Standard & Dwarfing \\
\hline KY93C-1238-17-1 & Sensitive & Insensitive & Dwarfing & Standard \\
\hline DINAH & Sensitive & Insensitive & & \\
\hline SS8700 & Sensitive & Insensitive & Standard & Dwarfing \\
\hline GA041293-11E54 & Sensitive & Insensitive & Standard & Dwarfing \\
\hline GA04434-11E44 & Sensitive & Insensitive & Standard & Dwarfing \\
\hline KY05C-1121-131-3-3 & Sensitive & Insensitive & Standard & Standard \\
\hline MD07W272-11-5 & Sensitive & Insensitive & Standard & Dwarfing \\
\hline Pioneer 26R61 & Sensitive & Insensitive & Standard & Dwarfing \\
\hline KY05C-1381-77-17-1 & Sensitive & Insensitive & Dwarfing & Standard \\
\hline MDC07026-12-10 & Sensitive & Insensitive & Standard & Dwarfing \\
\hline Pioneer 25R32 & Insensitive & Sensitive & Dwarfing & Standard \\
\hline BESS & Insensitive & Sensitive & Dwarfing & Standard \\
\hline VA09W-73 & Insensitive & Sensitive & Standard & Dwarfing \\
\hline LCS10516 & Insensitive & Sensitive & Standard & Dwarfing \\
\hline LCS19228 & Insensitive & Sensitive & Dwarfing & Standard \\
\hline LCS19229 & Insensitive & Sensitive & Dwarfing & Standard \\
\hline DANW1006 & Insensitive & Sensitive & Dwarfing & Standard \\
\hline DANW1008 & Insensitive & Sensitive & Dwarfing & Standard \\
\hline AGS2000 & Insensitive & Sensitive & Standard & Dwarfing \\
\hline DANW1003 & Insensitive & Sensitive & Dwarfing & Standard \\
\hline PEMBROKE 2014 & Insensitive & Insensitive & Dwarfing & Standard \\
\hline SSMPV57 & Insensitive & Insensitive & Standard & Standard \\
\hline BRANSON & Insensitive & Insensitive & Dwarfing & Standard \\
\hline PEMBROKE 2016 & Insensitive & Insensitive & Dwarfing & Standard \\
\hline SHIRLEY & Insensitive & Insensitive & Dwarfing & Standard \\
\hline KWS011 & Insensitive & Insensitive & Dwarfing & Standard \\
\hline KWS013 & Insensitive & Insensitive & Standard & Dwarfing \\
\hline VA11W-301 & Insensitive & Insensitive & Dwarfing & Standard \\
\hline JAMESTOWN & Insensitive & Insensitive & Standard & Dwarfing \\
\hline AR00255-16-1 & Insensitive & Insensitive & Standard & Dwarfing \\
\hline KY05C-1140-8-4-1 & Insensitive & Insensitive & Standard & Standard \\
\hline KY05C-1105-43-6-1 & Insensitive & Insensitive & Dwarfing & Standard \\
\hline OH07-264-35 & Insensitive & Insensitive & Dwarfing & Standard \\
\hline
\end{tabular}

\subsection{Soil Sampling}

Soil samples were collected three times within each treatment: prior to $\mathrm{N}$ application, when plants reached anthesis, and at physiological maturity. For each sampling, six soil cores were taken at a depth of $30 \mathrm{~cm}$ with a $1.6 \mathrm{~cm}$ diameter soil probe. The cores were combined, air dried and ground using a soil grinder.

Ammonium and nitrate were extracted from each soil sample using the $\mathrm{KCl}$ method [18]. A 2 mol $\mathrm{KCl}$ solution was prepared by diluting $150 \mathrm{~g} \mathrm{KCl}$ in $1000 \mathrm{~mL}$ of deionized water. Ten grams of soil were combined with $25 \mathrm{~mL}$ of $2 \mathrm{~mol} \mathrm{KCl}$ in $4 \mathrm{oz}$ specimen cups. The solution was mixed for $30 \mathrm{~min}$ by shaking on a reciprocal shaker for $30 \mathrm{~min}$ at $200 \mathrm{rpm}$. In total, $1 \mathrm{~mL}$ of solution was transferred to cluster tubes by pipette and cluster tubes were centrifuged for $27 \mathrm{~min}$. Aliquots (15 mL) of each sample and calibration standards were then pipetted into the wells of two microplates, one for the ammonium analysis and one for the nitrate analysis.

\subsection{Agronomic Traits and N Sampling}

Heading date was recorded when $50 \%$ of the plants in a headrow had visible spikes emerged from the flag leaf sheath. Anthesis date was recorded when $50 \%$ of the spikes had anthers extruding. Height was recorded prior to senescence and row length was recorded just before harvest. Chlorophyll 
content was measured using a SPAD $502 \mathrm{~m}$ (Konica Minolta, Tokyo, Japan). Readings were taken at anthesis by averaging measurements of five flag leaves per headrow together for the chlorophyll content index calculation.

Each headrow was harvested after physiological maturity at the soil surface and plants were placed into paper bags to be air dried in the greenhouse. Head number and total weight was recorded for each headrow. Head length was recorded from 5 heads and averaged. Plants were threshed and grain yield was measured. Vegetative biomass was determined by subtracting grain yield from the total plant weight.

Vegetative plant material from each headrow was ground to a powder using a cyclone mill (UDY One, Fort Collins, Colorado). Vegetative and whole grain subsamples were analyzed for protein concentration (\%) using Near Infrared Reflectance (NIR) on a DA7200 analyzer with a $950-1650 \mathrm{~nm}$ wavelength range (Perten, Hägersten, Sweden). Grain protein concentration was divided by 5.7 to convert to $\mathrm{N}$ concentration [19].

Total plant $\mathrm{N}$ uptake was determined by summing grain $\mathrm{N}$ (grain yield $* \%$ grain $\mathrm{N}$ content) $\left(\mathrm{kg} \mathrm{ha}^{-1}\right)$ and vegetative $\mathrm{N}$ at maturity (biomass yield $* \%$ vegetative $\left.\mathrm{N}\right)\left(\mathrm{kg} \mathrm{ha}^{-1}\right)$. Nitrogen use efficiency (NUE) and components of nitrogen uptake (NUpE) and utilization efficiency (NUtE) were calculated as: $\mathrm{NUE}=$ grain yield/soil N supply, $\mathrm{NUpE}=$ total plant $\mathrm{N} /$ Soil $\mathrm{N}$ Supply, NutE = grain yield/total plant $\mathrm{N}$ [20].

\subsection{Genotyping}

Genotyping for height (Rht-B1 and Rht-D1), vernalization (Vrn-A1, Vrn-B1 and Vrn-D3), and photoperiod (Ppd-A1, Ppd-B1, and Ppd-D1) QTL was done in the USDA-ARS Eastern Regional Small Grains Genotyping Laboratory in Raleigh, NC (https:/www.ars.usda.gov/southeast-area/raleigh-nc/ plant-science-research/docs/small-grains-genotyping-laboratory/main/) using KASP (Kompetitive allele specific PCR) markers.

\subsection{Statistical Analysis}

Analysis of variance (ANOVA) was performed using the General Linear Models procedure (Proc GLM; SAS 2011, Cary, North Carolina) to determine genotype and environment effects. The model used was:

$$
\mathrm{Yijkl}=\mu+\mathrm{ENV}_{i}+\mathrm{R}(\mathrm{ENV})_{i j}+\mathrm{YR}_{k}+\mathrm{G}_{l}+\mathrm{ENV}_{i} * \mathrm{G}_{l}+\mathrm{ENV}_{i}{ }^{*} \mathrm{YR}_{k}+\mathrm{G}_{l}{ }^{*} \mathrm{YR}_{k}+\mathrm{E}_{i j k l}
$$

where Yijkl = the observation in the lth genotype $(\mathrm{G})$ in the $j$ th rep $(\mathrm{R})$ in the $i$ th environment (ENV), in the $k$ th year (YR), $\mu=$ the overall mean, $\mathrm{R}(\mathrm{ENV}) i j=$ the effect of $j$ th rep within $i$ th environment, $E N V i$ * $\mathrm{Gl}=$ the effect of the interaction of the $i$ th environment and the $l$ th genotype, and Eijkl = the residual error. Least square means were estimated to measure environment differences among genotypes. Environment and interaction effects were considered significant if $p \leq 0.05$. Heritability was estimated in each environment over the two years of the study by equating mean squares to their expectations, using the following linear model:

$$
\mathrm{Y} i j k l=\mu+\mathrm{YR}_{i}+\mathrm{R}(\mathrm{YR})_{i j}+\mathrm{G}_{l}+\mathrm{YR} * \mathrm{G}_{l}+\mathrm{E}_{i j k l}
$$

where terms are as defined above. Confidence intervals were estimated according to Knapp et al. 1985 [21]. Proc CORR (SAS 2011) was used to analyze the relationship among traits on an entry mean basis.

\section{Results}

The canopy covers maintained a modest nighttime temperature increase during the months of active growth past dormancy. The temperature sensors were recording $24 \mathrm{~h}$ a day, every $15 \mathrm{~min}$, with 
the sampling interval for nightly temperatures set from 7 p.m.-7 a.m. to be consistent across seasons without considering fluctuating daylength. The average monthly night temperature increases in the passively warmed environment compared to the control environment across two seasons was $+0.7^{\circ} \mathrm{C}$ (April), $+0.41{ }^{\circ} \mathrm{C}$ (May), and $+0.60^{\circ} \mathrm{C}$ (June) (Table 2). The average monthly night temperatures were greater in 2015 than 2016 despite fewer overall growing degree days indicating that the diurnal range in 2015 was lower than 2016.

Table 2. Average monthly nighttime canopy temperatures and difference among environments in passively warmed and control environments, 2015-2016 season, Lexington KY. Sampling interval: 15 min, 7:00 p.m.-7:00 a.m.

\begin{tabular}{cccc}
\hline \multicolumn{4}{c}{$\mathbf{2 0 1 5}$} \\
\hline Month & Treatment Difference $\left({ }^{\circ} \mathbf{C}\right)$ & Warmed Environment $\left({ }^{\circ} \mathbf{C}\right)$ & Control Environment $\left({ }^{\circ} \mathbf{C}\right)$ \\
\hline April & 0.751 & 15.6 & 14.9 \\
May & 0.562 & 22.0 & 21.4 \\
June & 0.544 & 25.8 & 25.2 \\
\hline & & & \\
\hline March & 0.481 & 11.7 & 11.5 \\
April & 0.656 & 8.92 & 8.43 \\
May & 0.273 & 14.1 & 13.9 \\
June & 0.654 & 19.9 & 19.5 \\
\hline
\end{tabular}

There was a significant shift in average heading date across genotypes in the passively warmed treatment compared to the control treatment in the 2015 season ( 0.56 days, $p \leq 0.001)$ ) but no significant shift in 2016 ( 0.14 days) or in the combined analysis of both years (0.2 days) (Table 3). Across the two growing seasons, grain yield was significantly reduced by $6.4 \%$ or $224 \mathrm{~kg} \mathrm{ha}^{-1}(p \leq 0.05)$ in the passively warmed environment. Biomass was increased by $1.7 \%$ or $140 \mathrm{~kg} \mathrm{ha}^{-1}$ in the passively warmed environment but due to the reduction in grain yield the overall harvest index was significantly reduced ( $p \leq 0.01$ ) (Table 3). Height was significantly increased by $5 \mathrm{~cm}(p \leq 0.01)$ in the warmed environment explaining most of the increase in biomass. Spike density was significantly reduced by 26 spikes $\mathrm{m}^{-2}$ in the warmed environment $(p \leq 0.01$; Table 3$)$.

Table 3. Least squares means by environment for agronomic traits ${ }^{\dagger}$ measured on a panel of 36 soft red winter wheat genotypes under ambient and passively warmed conditions, 2015-2016 Lexington, KY. Least squares means were calculated from the combined ANOVA over years. Significance of mean squares shown below least squares means.

\begin{tabular}{|c|c|c|c|c|c|c|c|c|}
\hline Environment & $\begin{array}{l}\text { Heading Date } \\
\text { (DOY) }\end{array}$ & $\begin{array}{l}\text { Anthesis Date } \\
\text { (DOY) }\end{array}$ & Height $(\mathrm{cm})$ & Spikes $\mathrm{m}^{-2}$ & CCIa & Yield (kg ha-1) & $\begin{array}{l}\text { Biomass } \\
\left(\mathrm{kg} \mathrm{ha}^{-1}\right)\end{array}$ & $\begin{array}{c}\text { Harvest } \\
\text { Index }\end{array}$ \\
\hline Control & 126 & 129 & 76.0 & 529 & 49.1 & 3481 & 8062 & 0.32 \\
\hline Warming & 126 & 128 & 80.0 & 502 & 48.1 & 3257 & 8202 & 0.30 \\
\hline E & NS & NS & $<0.0001$ & $<0.01$ & $<0.01$ & $<0.05$ & NS & $<0.01$ \\
\hline $\mathrm{R}[\mathrm{E}]$ & NS & NS & $<0.01$ & NS & NS & NS & NS & $<0.01$ \\
\hline $\mathrm{Y}$ & $<0.0001$ & $<0.0001$ & $<0.0001$ & $<0.0001$ & $<0.0001$ & $<0.0001$ & $<0.0001$ & $<0.0001$ \\
\hline G & NS & NS & $<0.0001$ & $<0.0001$ & $<0.01$ & $<0.0001$ & $<0.0001$ & $<0.01$ \\
\hline$Y^{*} E$ & NS & NS & NS & $<0.01$ & $<0.01$ & NS & $<0.01$ & $<0.01$ \\
\hline$G^{*} Y$ & $<0.01$ & NS & $<0.0001$ & $<0.0001$ & NS & $<0.01$ & NS & $<0.05$ \\
\hline$G^{*} E$ & NS & NS & NS & NS & NS & NS & NS & NS \\
\hline
\end{tabular}

${ }^{\dagger}$ Environment (E), rep (R), year (Y), genotype (G), chlorophyll content index anthesis (CCIa).

Overall, NUE was reduced in the passively warmed environment but the differences were not statistically significant. There were no treatment differences for NUpE but NUtE was significantly reduced in the warmed environment $(p \leq 0.01)$ (Table 4$)$. There was significantly greater vegetative $\mathrm{N}$ content at maturity in the warmed environment $(p \leq 0.001)$ which helps to explain the difference in NUtE among environments, as well as a strong genotype by environment interaction effect for vegetative $\mathrm{N}$ content. Grain nitrogen contents were lower in the warmed treatment although the differences were not significant (Table 4). 
Table 4. Least squares means for nitrogen traits ${ }^{\dagger}$ measured on a panel of 36 soft red winter wheat genotypes under ambient and passively warmed conditions, 2015-2016 Lexington, KY. Least squares means were calculated from the combined ANOVA over years. Significance of mean squares shown below least squares means.

\begin{tabular}{|c|c|c|c|c|c|c|c|c|}
\hline Environment & 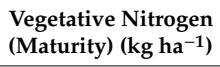 & $\begin{array}{c}\text { Grain } \\
\text { Protein }(\%)\end{array}$ & $\begin{array}{l}\text { Grain Nitrogen } \\
\left(\mathrm{kg} \mathrm{ha}^{-1}\right)\end{array}$ & $\begin{array}{c}\text { Total Plant } \\
\text { Nitrogen }\left(\mathrm{kg} \mathrm{ha}^{-1}\right)\end{array}$ & NHI (\%) & $\begin{array}{c}\text { NUtE } \\
\left(\mathrm{kg} \mathrm{kg}^{-1}\right)\end{array}$ & $\begin{array}{c}\mathrm{NUpE} \\
\left(\mathrm{kg} \mathrm{ha}^{-1}\right)\end{array}$ & $\begin{array}{c}\text { NUE } \\
\left(\mathrm{kg} \mathrm{kg}^{-1}\right)\end{array}$ \\
\hline Control & 68.3 & 13.0 & 72.3 & 140 & 0.533 & 26.2 & 1.24 & 27.0 \\
\hline Warming & 75.7 & 13.2 & 69.4 & 145 & 0.501 & 23.8 & 1.21 & 25.6 \\
\hline $\mathrm{R}[\mathrm{E}]$ & NS & NS & NS & NS & NS & NS & NS & NS \\
\hline Y & $<0.0001$ & $<0.0001$ & $<0.0001$ & $<0.0001$ & $<0.0001$ & $<0.0001$ & $<0.0001$ & $<0.0001$ \\
\hline G & $<0.0001$ & NS & $<0.0001$ & $<0.01$ & $<0.0001$ & $<0.1$ & $<0.01$ & $<0.0001$ \\
\hline$G^{*} E$ & $<0.05$ & NS & NS & NS & NS & NS & NS & NS \\
\hline
\end{tabular}

${ }^{\dagger}$ Nitrogen harvest index (NHI), Nitrogen utilization efficiency (NUtE), Nitrogen uptake efficiency (NUpE), Nitrogen use efficiency (NUE), Environment (E), rep (R), year $(\mathrm{Y})$, genotype $(\mathrm{G})$.

Similar results are seen when the screened genotypes are classified based on two reduced height loci (Rht-B1 and Rht-D1). Only the results for the Rht-B1 alleles are presented here with 16 of the genotypes screened having the wild-type or standard height allele (Rht-B1a) and 17 genotypes with the dwarfing or reduced height allele (Rht-B1b) (Table 5). Genotypes with either wild type or reduced height alleles had a significant increase in height with passive canopy warming, with an average increase of 3.5 and $4.6 \mathrm{~cm}$ respectively. Yield was significantly reduced by an average of $8.4 \%$ in the passive warmed environment for those genotypes with the dwarfing allele (Rht-B1b). While yield of Rht-B1a genotypes was also reduced, the magnitude was a non-significant $3.8 \%$. These yield responses to canopy warming may be attributable to a significant $(p<0.1)$ reduction in NUtE. The significant increases in vegetative nitrogen content are likely due to the increases in biomass, associated with the significant height increases in the warmed environment. This $\mathrm{N}$ content is not being translocated to the grain, as grain protein was not increased across treatments (Table 4).

The screened genotypes were also classified by allelic variation at the photoperiod sensitivity (PPD-D1) locus. Of the 36 genotypes represented in the study, 12 genotypes possess photoperiod sensitive alleles and 24 are photoperiod insensitive at the PPD-D1 locus. There were no significant differences across environments within $P P D$ classifications for grain yield or NUE traits (Table 6). There was a greater reduction in yield among the $P P D$ sensitive genotypes $(9.28 \%)$ and a reduction in biomass, whereas the PPD insensitive genotypes remained relatively stable for grain yield and had a biomass increase in the warmed environment, although these results were not statistically significant. Height was significantly increased in the passively warmed treatment for both $P P D$ sensitive $(3.97 \mathrm{~cm})$ and insensitive genotypes $(4.16 \mathrm{~cm})$ (Table 6).

There was significant genotypic variation $(p \leq 0.05)$ for all agronomic and NUE traits measured except for heading and anthesis dates and grain protein concentration but no significant genotype $\times$ environment interactions (Table 3, Table 4). While $\mathrm{G} \times \mathrm{E}$ interaction was not significant across genotypes, ten genotypes had significantly increased yields in the passively warmed treatment $(p \leq 0.05)$ (Table 7). These lines also had significant increases in NUE in the warmed treatment compared to the control. The increase in NUE was associated with NUpE in some instances and with NUtE in others; the response was not consistent across genotypes. Four genotypes had a significant positive increase in NUpE and increased total plant $\mathrm{N}\left(\mathrm{kg} \mathrm{ha}^{-1}\right)$ in the warmed environment $(p \leq 0.05)$ (DANW1008, GA041293-11E54, KY05C-1105-43-6-1, MDC07026-12-10), and only one genotype (GA04434-11E44) had a significant positive increase in NUtE $(p \leq 0.05)$. Additionally, KY05C-1105-43-6-1, VA11W-301, KY05C-1381-77-17-1, and PEMBROKE 2016 had significant increases in biomass production $(p \leq 0.05)$ in addition to a positive grain yield response in the warmed environment. Responses to warming of all 36 genotypes in both agronomic and nitrogen use traits are shown in Supplemental Tables S1-S8. 
Table 5. Least squares means of agronomic traits ${ }^{\dagger}$ in control and passively warmed environments based on height classification at the Rht-B1 locus of 36 soft red winter wheat genotypes, 2015-2016 Lexington, KY.

\begin{tabular}{|c|c|c|c|c|c|c|c|c|c|c|c|}
\hline Environment & $\begin{array}{c}\text { Heading } \\
\text { Date (DOY) }\end{array}$ & $\begin{array}{c}\text { Anthesis } \\
\text { Date (DOY) }\end{array}$ & $\begin{array}{l}\text { Height } \\
(\mathrm{cm})\end{array}$ & $\begin{array}{c}\text { Spikes } \\
\mathrm{m}^{-2}\end{array}$ & $\begin{array}{c}\text { Yield } \\
\left(\mathrm{kg} \mathrm{ha}^{-1}\right)\end{array}$ & $\begin{array}{c}\text { Biomass } \\
\left(\mathrm{kg} \mathrm{ha}^{-1}\right)\end{array}$ & $\begin{array}{c}\text { Vegetative } \\
\text { Nitrogen (Maturity) } \\
\left(\mathrm{kg} \mathrm{ha}^{-1}\right)\end{array}$ & NUE & $\begin{array}{c}\mathrm{NUtE} \\
\left(\mathrm{kg} \mathrm{kg}^{-1}\right)\end{array}$ & $\begin{array}{c}\text { NUpE } \\
\left(\mathrm{kg} \mathrm{ha}^{-1}\right)\end{array}$ & $\begin{array}{c}\text { Grain } \\
\text { Protein }(\%)\end{array}$ \\
\hline \multicolumn{12}{|c|}{ Standard Height (Rht-B1a) $n=16$} \\
\hline Control & 126 & 129 & 75.4 & 528 & 3317 & 7945 & 0.833 & 25.5 & 25.8 & 1.23 & 12.9 \\
\hline Warmed & 125 & 128 & 78.9 & 502 & 3192 & 8193 & 0.881 & 25.1 & 23.9 & 1.21 & 13.1 \\
\hline$p$ value & 0.15 & NS & $<0.0001$ & 0.16 & NS & NS & 0.1 & NS & 0.1 & NS & 0.1 \\
\hline \multicolumn{12}{|c|}{ Reduced Height (Rht-B1b) $n=17$} \\
\hline Control & 126 & 129 & 76.5 & 529 & 3629 & 8166 & 0.814 & 28.3 & 26.6 & 1.21 & 13.1 \\
\hline Warmed & 126 & 129 & 81.1 & 502 & 3324 & 8211 & 0.912 & 26.1 & 23.7 & 1.34 & 13.2 \\
\hline$p$ value & NS & NS & $<0.001$ & 0.15 & 0.04 & NS & 0.0018 & 0.06 & 0.0005 & NS & NS \\
\hline
\end{tabular}

${ }^{\dagger}$ Nitrogen utilization efficiency (NUtE), Nitrogen uptake efficiency (NUpE).

Table 6. Least squares means of agronomic traits ${ }^{\dagger}$ in control and passively warmed environments based on photoperiod classification of 36 soft red winter wheat genotypes, 2015-2016 Lexington, KY.

\begin{tabular}{|c|c|c|c|c|c|c|c|c|c|}
\hline Environment & $\begin{array}{l}\text { Heading Date } \\
\text { (DOY) }\end{array}$ & $\begin{array}{c}\text { Anthesis } \\
\text { Date (DOY) }\end{array}$ & Height (cm) & Spikes $\mathbf{m}^{-2}$ & $\begin{array}{c}\text { Yield } \\
\left(\mathrm{kg} \mathrm{ha}^{-1}\right)\end{array}$ & $\begin{array}{l}\text { Biomass } \\
\left(\text { kg ha }^{-1}\right)\end{array}$ & $\begin{array}{l}\text { Vegetative Nitrogen } \\
\text { (Maturity) }\left(\mathrm{kg} \mathrm{ha}^{-1}\right)\end{array}$ & $\begin{array}{c}\text { NUtE } \\
\left(\mathrm{kg} \mathrm{kg}^{-1}\right)\end{array}$ & $\begin{array}{c}\mathrm{NUpE} \\
\left(\mathrm{kg} \mathrm{ha}^{-1}\right)\end{array}$ \\
\hline \multicolumn{10}{|c|}{ Photoperiod Sensitive (PPD-D1) $n=12$} \\
\hline Control & 127 & 129 & 80.2 & 543 & 3711 & 8687 & 69.2 & 26.3 & 1.27 \\
\hline Warmed & 126 & 129 & 84.1 & 493 & 3330 & 8436 & 77.9 & 23.9 & 1.26 \\
\hline$p$ value & NS & NS & $<0.01$ & $<0.1$ & NS & NS & NS & NS & NS \\
\hline \multicolumn{10}{|c|}{ Photoperiod Insensitive (PPD-D1a) $n=24$} \\
\hline Control & 126 & 128 & 73.9 & 522 & 3367 & 7750 & 68.2 & 26.1 & 1.16 \\
\hline Warmed & 126 & 128 & 78.0 & 507 & 3214 & 8086 & 74.8 & 23.5 & 1.22 \\
\hline$p$ value & NS & NS & $<0.001$ & NS & NS & NS & NS & NS & NS \\
\hline
\end{tabular}

${ }^{\dagger}$ Nitrogen utilization efficiency (NUtE), Nitrogen uptake efficiency (NUpE). 
Table 7. Least squares means of lines with increased grain yields in a passively warmed environment. Agronomic and nitrogen traits ${ }^{\dagger}$ in a panel of 36 soft red winter wheat genotypes grown in control and passively warmed environments over 2 growing seasons, 2015-2016, Lexington, KY.

\begin{tabular}{|c|c|c|c|c|c|c|c|c|c|c|c|c|c|c|c|}
\hline \multirow[b]{2}{*}{ Genotype } & \multirow[b]{2}{*}{$\begin{array}{c}\text { Yield } \\
\left(\mathrm{kg} \mathrm{ha}^{-1}\right)\end{array}$} & \multicolumn{5}{|c|}{ Warmed Environment } & \multicolumn{9}{|c|}{ Control Environment } \\
\hline & & $\begin{array}{c}\text { Biomass } \\
\left(\mathrm{kg} \mathrm{ha}^{-1}\right)\end{array}$ & $\begin{array}{c}\text { Total Plant } \\
\text { Nitrogen } \\
\left(\mathbf{k g ~ h a}^{-1}\right)\end{array}$ & $\begin{array}{l}\text { NHI } \\
(\%)\end{array}$ & $\begin{array}{c}\text { NUtE } \\
\left(\mathrm{kg} \mathrm{kg}^{-1}\right)\end{array}$ & $\begin{array}{c}\mathrm{NUpE} \\
\left(\mathrm{kg} \mathrm{ha}^{-1}\right)\end{array}$ & NUE & $\begin{array}{c}\text { Yield } \\
\left(\mathrm{kg} \mathrm{ha}^{-1}\right)\end{array}$ & $\begin{array}{c}\text { Biomass } \\
\left(\mathrm{kg} \mathrm{ha}^{-1}\right)\end{array}$ & $\begin{array}{c}\text { Total Plant } \\
\text { Nitrogen } \\
\left(\text { kg ha }^{-1}\right)\end{array}$ & $\begin{array}{l}\text { NHI } \\
(\%)\end{array}$ & $\begin{array}{c}\text { NUtE } \\
\left(\mathrm{kg} \mathrm{kg}^{-1}\right)\end{array}$ & $\begin{array}{c}\mathrm{NUpE} \\
\left(\mathrm{kg} \mathrm{ha}^{-1}\right)\end{array}$ & NUE & $\begin{array}{c}P P D \\
\text { A1/D1 }\end{array}$ \\
\hline KWS013 & $3061 *$ & 6875 & 124.9 & $0.501 *$ & $26.0 *$ & 1.06 & $23.1 *$ & 2539 & 6905 & 129.0 & 0.461 & 23.6 & 1.14 & 19.6 & $\mathrm{I} / \mathrm{I}$ \\
\hline DANW1008 & $3329 *$ & 9205 & $156.3 *$ & 0.474 & 22.3 & 1.34 * & $26.8^{*}$ & 2803 & 9167 & 137.4 & 0.474 & 22.8 & 1.21 & 22.8 & $\mathrm{I} / \mathrm{S}$ \\
\hline GA041293-11E54 & $3454 *$ & $7520 *$ & $141.7^{*}$ & 0.524 & 25.1 & $1.20 *$ & 26.5 * & 2959 & 6928 & 116.9 & 0.552 & 26.1 & 1.00 & 23.0 & $\mathrm{~S} / \mathrm{I}$ \\
\hline GA04434-11E44 & $2895 *$ & 7891 & 138.9 & $0.512 *$ & $23.9 *$ & 1.20 & 25.1 * & 2490 & 8543 & 152.1 & 0.36 & 17.6 & 1.33 & 20.1 & $\mathrm{~S} / \mathrm{I}$ \\
\hline KY05C-1105-43-6-1 & $3973 *$ & $8197 *$ & $153.2 *$ & 0.532 & 25.6 & 1.30 * & 30.1 * & 3529 & 7180 & 124.2 & 0.572 & 27.9 & 1.03 & 26.7 & $\mathrm{I} / \mathrm{I}$ \\
\hline Bess & $3795 *$ & 7795 & 127.8 & 0.591 & 28.8 & 1.04 & 29.1 * & 3403 & 7905 & 126.0 & 0.613 & 28.9 & 1.08 & 27.3 & $\mathrm{I} / \mathrm{S}$ \\
\hline VA11W-301 & 3277 * & 8030 * & 146.6 & 0.494 & 24.0 & 1.30 & 25.5 * & 2982 & 6995 & 147.6 & 0.501 & 24.4 & 1.30 & 23.0 & $\mathrm{I} / \mathrm{I}$ \\
\hline MDC07026-12-10 & $3436 *$ & $7703 *$ & $151.9^{*}$ & 0.492 & 23.5 & 1.30 * & 26.6 * & 3131 & 7104 & 130.5 & 0.513 & 24.8 & 1.14 & 22.7 & $\mathrm{~S} / \mathrm{I}$ \\
\hline КY05C-1381-77-17-1 & 3908 * & $9299 *$ & 139.6 & $0.592 *$ & 28.4 & 1.20 & $31.0 *$ & 3590 & 7674 & 136.7 & 0.564 & 27.6 & 1.15 & 27.4 & $\mathrm{~S} / \mathrm{I}$ \\
\hline PEMBROKE 2016 & $3565 *$ & $11678 *$ & 149.6 & 0.483 & 22.9 & 1.20 & 27.7 * & 3345 & 7712 & 142.5 & 0.491 & 24.3 & 1.20 & 25.4 & $\mathrm{I} / \mathrm{I}$ \\
\hline
\end{tabular}

${ }^{\dagger}$ Nitrogen harvest index (NHI), Nitrogen utilization efficiency (NUtE), Nitrogen uptake efficiency (NUpE), Nitrogen use efficiency (NUE). ${ }^{*}$ Denotes significant increases in warming treatment at $p \leq 0.05$ 
The entries in Table 7 are in contrast to lines like KWS 011 which showed a 49\% drop in yield in response to warming when averages over both years of the study (data not shown). Heritability estimates and $90 \%$ confidence intervals are presented in Table 8 . In general, heritability estimates in the control environment were greater than those estimated under warming.

Table 8. Heritability estimates ${ }^{\dagger}$ and $90 \%$ confidence intervals from a SRW wheat genotype panel grown in control and passively warmed environments, Lexington, KY, 2015-2016.

\begin{tabular}{|c|c|c|c|c|c|c|}
\hline \multirow{2}{*}{ Trait } & \multicolumn{3}{|c|}{ Control Environment } & \multicolumn{3}{|c|}{ Warmed Environment } \\
\hline & $h^{2}$ & LL & UL & $h^{2}$ & LL & UL \\
\hline Height $(\mathrm{cm})$ & 0.66 & 0.38 & 0.81 & 0.67 & 0.41 & 0.81 \\
\hline Spikes $\mathrm{m}^{-2}$ & 0.11 & -0.59 & 0.49 & 0.11 & -0.59 & 0.49 \\
\hline CCIa & 0.24 & -0.35 & 0.57 & 0.33 & 0.16 & 0.62 \\
\hline Harvest Index & 0.20 & -0.43 & 0.54 & 0 & & \\
\hline Yield $\left(\mathrm{kg} \mathrm{ha}^{-1}\right)$ & 0.05 & -0.69 & 0.46 & 0 & & \\
\hline Biomass $\left(\mathrm{kg} \mathrm{ha}^{-1}\right)$ & 0.18 & -0.46 & 0.54 & 0.52 & 0.15 & 0.73 \\
\hline $\begin{array}{l}\text { Vegetative N Concentration (\%) } \\
\text { (Maturity) }\end{array}$ & 0.51 & 0.12 & 0.72 & 0.54 & 0.11 & 0.72 \\
\hline $\begin{array}{c}\text { Total Vegetative } \mathrm{N}\left(\mathrm{kg} \mathrm{ha}^{-1}\right) \\
\text { (Maturity) }\end{array}$ & 0.39 & 0.01 & 0.65 & 0 & & \\
\hline Grain Protein (\%) & 0 & & & 0.41 & -0.06 & 0.66 \\
\hline Grain N Content $\left(\mathrm{kg} \mathrm{ha}^{-1}\right)$ & 0.16 & -0.05 & 0.52 & 0.01 & -0.78 & 0.43 \\
\hline $\mathrm{NHI}$ & 0.39 & 0.09 & 0.65 & 0 & & \\
\hline NUpE & 0 & & & 0 & & \\
\hline NUtE & 0.28 & -0.29 & 0.59 & 0 & & \\
\hline NUE & 0.09 & -0.63 & 0.48 & 0.05 & -0.7 & 0.46 \\
\hline
\end{tabular}

$+\overline{\text { Nitrogen harvest index (NHI), Nitrogen uptake efficiency (NUpE), Nitrogen utilization efficiency (NUtE), Nitrogen }}$ use efficiency (NUE).

\section{Discussion}

This study was initiated to explore genetic variation in the adaptation of wheat response to nighttime temperature increases and to determine the role that NUE and its constituent traits play when temperature stress is experienced during the critical period for grain yield determination.

In their study of passive warming in field studies, Beier et al. 2004 [20] suggest a potential range of $0.5-2.0^{\circ} \mathrm{C}$ when using reflective curtains in a field environment. The temperature increase in this experiment fell within this range in that the reduction in heat loss in the warmed environment was roughly $64 \%$ of that observed in uncovered control plots. This field experiment allowed for free air movement and no significant change in soil moisture or light interception. We did not measure edge effects in the covered plots in this experiment but no significant edge effects were found in previous research trials [20]. However, border headrows were placed along the edges of the covered plots as a buffer for such unintended edge effects. Timing of passive warming in this experiment captured the critical period for grain yield determination as defined by Zadoks et al. 1974 [22] from penultimate leaf appearance to the beginning of active grain filling or 10 days after anthesis [10].

Reduced grain yield, linked to a decrease in spikes $\mathrm{m}^{-2}$, is similar to the results of Garcia et al. 2015 [10], Hein et al. 2019 [12] and Zhang et al. 2013 [14] in experiments utilizing heating chambers in field conditions during night hours. This similarity was observed, despite the lower temperature increases sustained in our passively warmed environment in comparison to other warming studies. The overall reduction in grain yield with a less than $1^{\circ} \mathrm{C}$ increase in nighttime temperature during the critical period was $6 \%$. This decrease in grain yield is similar to the findings of Garcia et al. 2015 [10] and Fischer et al. 2014 [23] in experiments resulting in 5\% to 7\% reductions in grain yield for every $1{ }^{\circ} \mathrm{C}$ increase in nighttime temperatures.

The reduction in grain yield and the uptake and translocation of $\mathrm{N}$ in a passively warmed environment with increased nighttime temperatures agree with the experimental results of Zhang et al. 
2013 [24]. Increased night temperatures and a reduced diurnal range appear to increase total $\mathrm{N}$ uptake but lower NUtE leaving excess $\mathrm{N}$ in the vegetative material not being transferred to grain yield.

Plant height was dramatically increased by passive warming $(p<0.01$; Table 3$)$. Biomass was numerically, though not significantly, higher in the warmed treatment than in the control, reflecting, in part, the increased height. Harvest index was significantly reduced under passive warming $(p<0.01$; Table 3). These two traits represent a sharp contrast to a companion active soil warming study [25], in which both height and harvest index were the only agronomic traits unaffected by warming. A further difference between the two studies is the fact that heading or anthesis dates were largely unaffected by passive warming, while both were dramatically hastened by active soil warming. The lack of a significant shift in phenology is likely explained by the inter-year variation in temperatures seen in Table 2, when analyzed by year separately we do see a significant shift in earlier heading and anthesis dates for the 2015 season similar to Russell and Van Sanford 2018 [25]. Fan et al., 2015 [26] display results indicating a greater shift in phenology due to increased night temperatures during winter months compared to spring months while both resulted in earlier shifts in anthesis dates. As such, winter warming increased yield more so than spring night warming in their study.

On the other hand, passive warming had a highly significant impact on $\mathrm{N}$ partitioning (Table 4). Vegetative $\mathrm{N}$ at maturity was increased while $\mathrm{N}$ harvest index and $\mathrm{N}$ utilization efficiency were both lower in the warmed environment. Interestingly, none of these traits are affected by active soil warming [25].

The breeding lines and cultivars listed in Table 7 are those that responded positively to warming, in terms of grain yield. Four of these lines were among those with higher yields in our active warming study [25]. In that study higher grain yields under warming were accompanied by higher biomass in 10 of 13 lines. In the present study, six of 10 lines had increased biomass along with increased grain yield in the warmed environment. Of these, only DANW1008 and Pembroke 2016 also had greater biomass than in the control environment. Such variation is not surprising and is just another example of the different yield strategies used by different genotypes. This same variability was reported recently by Hitz et al. 2016 [27].

One of the primary objectives of this study was to quantify genotypic variation in the panel of lines evaluated in both environments. Heritability estimates and $90 \%$ confidence intervals are presented in Table 8. A reduced linear model was used to estimate heritability in each environment separately. Estimates of zero (0) are presented for the cases in which the genotype effect was not significantly different from zero. We knew at the outset that a single row is not an ideal experimental unit for estimating a quantitative trait like yield, but in order to accommodate a genotype panel of any size, the experimental unit was required to have a small footprint to fit the warming infrastructure that was available.

One of the criteria used to evaluate the warming method is whether it provides a platform for selecting genotypes that are better adapted to a warmer climate. The estimates of heritability from the study shed some light on that question. Based on this two-year study, and with respect to this set of genotypes, it appears that the warmed environment would be superior to the control in selecting for biomass, chlorophyll concentration at anthesis, grain protein, and vegetative $\mathrm{N}$ concentration at maturity. In contrast to a companion active warming study, however, heritabilities in this study were generally lower in the warmed treatment than in the control [25]. The expectation at the outset of the study was that a temperature difference of $1^{\circ} \mathrm{C}$ would be maintained between control and warmed environments; that difference was not achieved, which may have impacted the magnitude of the differences in genetic parameters we estimated.

Exploiting genetic variation for improved $\mathrm{N}$ use traits, for example, those that contribute to vegetative growth as measured in this study, may continue to be an important breeding strategy to combat yield losses due to changing climate, particularly in regard to increasing nighttime temperatures. Li et al., 2019 [28] recently tested the effects of night warming on gluten strength and found improved wheat quality traits among cultivars in warmed conditions. Experimental designs testing the effects 
of warming on crop yields must account for genetic variation in response to warming. By including genetic variation in experiments that test physiological mechanisms, plant breeders will be able to devise more informed selection criteria to further adaptation to increasing temperatures.

Supplementary Materials: The following are available online at http://www.mdpi.com/2073-4395/10/4/531/s1, Table S1: LSMeans from control environments for agronomic traitst in a panel of 36 soft red winter wheat genotypes, Lexington, KY, 2015. Mean, coefficient of variation (CV), and standard error (SE) from ANOVA, Table S2: LSMeans for control environment for nitrogen traitst for a panel of $36 \mathrm{soft}$ red winter wheat genotypes, Lexington, KY, 2015. Mean, coefficient of variation (CV), and standard error (SE) from ANOVA, Table S3: LSMeans from passive warmed environments for agronomic traitst in a panel of $36 \mathrm{soft}$ red winter wheat genotypes, Lexington, KY, 2015. Mean, coefficient of variation (CV), and standard error (SE) from ANOVA, Table S4: LSMeans for passive warmed environment for nitrogen traitst for a panel of 36 soft red winter wheat genotypes, Lexington, KY, 2015. Mean, coefficient of variation (CV), and standard error (SE) from ANOVA, Table S5: LSMeans from control environments for agronomic traitst in a panel of 36 soft red winter wheat genotypes, Lexington, $\mathrm{KY}$, 2016. Mean, coefficient of variation (CV), and standard error (SE) from ANOVA, Table S6: LSMeans for control environment for nitrogen traitst for a panel of 36 soft red winter wheat genotypes, Lexington, KY, 2016. Mean, coefficient of variation (CV), and standard error (SE) from ANOVA, Table S7: LSMeans from passive warmed environments for agronomic traitst in a panel of 36 soft red winter wheat genotypes, Lexington, KY, 2016. Mean, coefficient of variation (CV), and standard error (SE) from ANOVA, Table S8: LSMeans for passive warmed environment for nitrogen traitst for a panel of 36 soft red winter wheat genotypes, Lexington, KY, 2016. Mean, coefficient of variation (CV), and standard error (SE) from ANOVA.

Author Contributions: K.R. and D.A.V.S. conceived and designed the experiments; K.R. performed the experiments; K.R. and D.A.V.S. analyzed the data; K.R. wrote the paper, D.A.V.S. edited it. All authors have read and agreed to the published version of the manuscript.

Funding: This work was funded in part by a grant from USDA-NIFA-AFRI Triticeae Coordinated Agricultural Project, 2011-68002-30029, and a grant from the Kentucky Small Grain Promotion Council.

Acknowledgments: We thank James Dollarhide for designing and implementing the passive warming infrastructure, John Multhouse of the Sevilleta LTER for advice on the thermal fabric and infrastructure design, and John Connelley for technical assistance.

Conflicts of Interest: The authors declare no conflict of interest.

\section{References}

1. Knowles, N.; Dettinger, M.D.; Cayan, D.R. Trends in snowfall versus rainfall in the western United States. J. Climatol. 2006, 19, 4545-4559. [CrossRef]

2. Hatfield, J.L.; Boote, K.J.; Kimball, B.A.; Ziska, L.H.; Izaurralde, R.C.; Ort, D.; Thomson, A.M.; Wolf, D. Climate impacts on agriculture: Implications for Crop Production. Agron. J. 2011, 103, 351-370. [CrossRef]

3. Karl, T.R.; Melillo, J.M.; Peterson, T.C. Global Climate Change Impacts in the United States; Cambridge University Press: New York, NY, USA, 2009.

4. Moot, D.J.; Henderson, A.L.; Porter, J.R.; Semenov, M.A. Temperature, $\mathrm{CO}_{2}$ and the growth and development of wheat: Changes in the means and variability of growing conditions. Clim. Chang. 1996, 33, 351-368. [CrossRef]

5. Horton, B. The geographical distribution of changes in maximum and minimum temperatures. J. Appl. Meteorol. 1995, 37, 101-117. [CrossRef]

6. Vincent, L.A.; Mekis, E. Changes in daily and extreme temperature and precipitation indices for Canada over the twentieth century. Atmos. Ocean 2006, 44, 177-193. [CrossRef]

7. Sadras, V.; Dreccer, M.F. Adaptation of wheat, barley, canola, field pea and chickpea to the thermal environments of Australia. Crop Pasture Sci. 2015, 66, 1137-1150. [CrossRef]

8. Hatfield, J.L.; Prueger, J.H. Temperature extremes: Effect on plant growth and development. Weather Clim. Extrem. 2015, 10, 4-10. [CrossRef]

9. Peraudeau, S.; Lafarge, T.; Roques, S.; Quinones, C.O.; Clément-Vidal, A.; Ouwerkerk, P.B.F.; Rie, J.V.; Fabre, D.; Jagadish, K.; Dingkuhn, M. Effect of carbohydrates and night temperature on night respiration in rice. J. Exp. Bot. 2015, 66, 3931-3944. [CrossRef]

10. Garcia, G.; Dreccer, M.F.; Miralles, D.J.; Serrago, R. High night temperatures during grain number determination reduce wheat and barley grain yield: A field study. Glob. Chang. Biol. 2015, 21, 4153-4164. [CrossRef] 
11. Prasad, P.V.V.; Pisipati, S.R.; Ristic, Z.; Bukovnik, U.; Fritz, A.K. Effect of nighttime temperature on physiology and growth of spring wheat. Crop Sci. 2008, 48, 2372-2380. [CrossRef]

12. Hein, N.T.; Wagner, D.; Bheemanahalli, R. Integrating field-based heat tents and cyber-physical system technology to phenotype high night-time temperature impact on winter wheat. Plant Methods 2019, 15, 41. [CrossRef] [PubMed]

13. Tian, Y.; Zheng, C.; Chen, J.; Chen, C.; Deng, A.; Song, Z.; Zhang, B.; Zhang, W. Climatic warming increases winter wheat yield but reduces grain nitrogen concentration in East China. PLoS ONE 2014, 9, e95108. [CrossRef] [PubMed]

14. Zhao, C.; Piao, S.; Huang, Y.; Wang, X.; Ciais, P.; Huang, M.; Zeng, Z.; Peng, S. Field warming experiments shed light on the wheat yield response to temperature in China. Nat. Commun. 2016, 7, 13530. [CrossRef] [PubMed]

15. Sage, R.F.; Kubien, D.S. The temperature response of $C_{3}$ and $C_{4}$ photosynthesis. Plant Cell Environ. 2007, 30, 1086-1106. [CrossRef]

16. Lutt, N.; Jeschke, M.; Strachan, S.D. High night temperature effects on corn yield. DuPont Pioneer Agronomy Sciences. Crop Insights 2016, 26, 16.

17. Peters, D.B.; Pendleton, J.W.; Hageman, R.H.; Brown, C.M. Effect of night air temperature on grain yield of corn, wheat, and soybeans. Agron. J. 1972, 63, 809. [CrossRef]

18. Crutchfield, J.D.; Grove, J.H. A new cadmium reduction device for the microplate determination of nitrate in water, soil, plant tissue and physiological fluids. J. AOAC Int. 2011, 94, 1896-1905. [CrossRef]

19. Moll, R.H.; Kamprath, E.J.; Jackson, W.A. Analysis and interpretation of factors which contribute to efficiency to nitrogen utilization. Agron. J. 1982, 74, 562-564. [CrossRef]

20. Beier, C.; Emmett, B.; Gundersen, P.; Tietema, A.; Penuelas, J.; Estiarte, M.; Gordon, C.; Gorissen, A.; Llorens, L.; Roda, F.; et al. Novel approaches to study climate change effects on terrestrial ecosystems in the field: Drought and passive nighttime warming. Ecosystems 2004, 7, 583-597. [CrossRef]

21. Knapp, S.J.; Stroup, W.W.; Ross, W.M. Exact confidence intervals for heritability on a progeny mean basis. Crop Sci. 1985, 25, 192-194. [CrossRef]

22. Zadoks, J.C.; Chang, T.T.; Konzak, C.F. A Decimal Code for the Growth Stages of Cereals. Weed Res. 1974, 14, 415-421. [CrossRef]

23. Fischer, R.A.; Byerlee, D.A.; Edmeades, G. Crop yields and global food security: Will yield increase contribute to feed the world? ACIAR Monogr. 2014, 158, 8-11.

24. Zhang, Y.; Li, R.; Wang, Y. Night-time warming affects $\mathrm{N}$ and $\mathrm{P}$ dynamics and productivity of winter wheat plants. Can. J Plant Sci. 2013, 93, 397-406. [CrossRef]

25. Russell, K.; Van Sanford, D.A. Breeding for Resilience to Increasing Temperatures: A Field Trial Assessing Genetic Variation in Soft Red Winter Wheat. Ecol. Evol. 2018. [CrossRef] [PubMed]

26. Fan, Y.; Tian, M.; Jing, Q.; Tian, Z.; Han, H.; Jiang, D.; Cao, W.; Dai, T. Winter night warming improves pre-anthesis crop growth and post-anthesis photosynthesis involved in grain yield of winter wheat (Triticum aestivum L.). Field Crops Res. 2015, 178, 100-108. [CrossRef]

27. Hitz, K.; Clark, A.J.; Van Sanford, D.A. Identifying nitrogen-use efficient soft red winter wheat lines in high and low nitrogen environments. Field Crops Res. 2016, 200, 1-9. [CrossRef]

28. Li, S.; Wang, J.; Ding, M.; Min, D.; Wang, Z.; Gao, X. The influence of night warming treatment on the micro-structure of gluten in two wheat cultivars. Food Res. Int. 2019, 116, 329-335. [CrossRef]

(C) 2020 by the authors. Licensee MDPI, Basel, Switzerland. This article is an open access article distributed under the terms and conditions of the Creative Commons Attribution (CC BY) license (http://creativecommons.org/licenses/by/4.0/). 